Jan Mazur OSPPE

Uniwersytet Papieski Jana Pawła II w Krakowie

\title{
Problem prekaryjnej pracy w kontekście dyskusji o polityce społecznej w Polsce
}

DOI: $10.19195 / 1643-0328.23 .6$

Słowa kluczowe: prekariat, praca prekaryjna, umowa o pracę, niepewne formy zatrudnienia, pracownicy etatowi, umowa cywilnoprawna, bezrobocie, rynek pracy

\section{Wprowadzenie}

Problem pracy prekaryjnej, względnie prekariackiej, wpisuje się w szerszą dyskusję na temat prekariatu, który od wielu już lat postrzegany jest jako nowa kategoria społeczna. Warto tej kategorii przyjrzeć się nieco bliżej, by uchwycić kryjące się w niej najważniejsze wyzwania związane z polityką społeczną. Aby podjąć zagadnienie pracy prekaryjnej, najpierw trzeba uświadomić sobie, na czym polega, w czym wyraża się jej status quaestionis. Następnie można dopiero podjąć refleksję w formie uwag na temat pracy prekaryjnej w aspekcie problemów stojących przed polityką społeczną w Polsce.

\section{Wgląd w zjawisko i problem prekariatu}

Nie sposób nie zauważyć, że słowo prekarium (w liczbie mnogiej prekaria), jak również terminy „władztwo prekaryjne” czy „prekarzysta” od dawna używane są w języku prawniczym. Prekarium oznacza rodzaj instytucji prawnej, która w przeszłości miała duże znaczenie dla rozwoju feudalnych stosunków zależności. Termin „praca prekaryjna” zachowuje jednak odrębność znaczeniową w odniesieniu do słowa „prekarium”, które nie wchodzi w zakres niniejszych rozważań.

Wyrażenie „praca prekaryjna” jest bowiem zwiazane ze słowem „prekariat”. Przywoływane jest ono na określenie ludzi, którzy utrzymują siebie i swoją rodzinę na podstawie pracy zarobkowej niskiej jakości, przeważnie naznaczonej niepewnością, tymczasowością, niską płacą, brakiem umowy, pozbawionej perspektyw awansu, zabezpieczeń itp. $\mathrm{Ci}$, którzy przynależą do prekariatu, określani są mianem prekariuszy. Są to osoby podejmujące pracę zarobkową na podstawie elastycznych form zatrudnienia i $z$ tego powodu 
pozbawieni są zadowalających perspektyw życiowych. Należą do nich: seryjni stażyści, pracownicy tymczasowi, młodzi bezrobotni lub pracujący poniżej swojego wykształcenia. Prekariat można scharakteryzować za pośrednictwem sformułowań: umowy „śmieciowe", niepewne zatrudnienie, minimalna płaca krajowa, nieludzkie nadgodziny, brak tożsamości zawodowej, nikłe składki emerytalne lub ich całkowity brak ${ }^{1}$.

W ramach status quaestionis warto jeszcze nieco miejsca poświęcić etymologii. Otóż w niemal powszechnym przekonaniu słowo „prekariat” uchodzi za neologizm powstały z połączenia dwóch słów: precarious (ang. niepewny) i „proletariat”. Należy wszakże pamiętać, że znaczna część angielskiej terminologii ma pochodzenie łacińskie. Słowo precarious wykazuje podobieństwo do łacińskiego precarium, co można tłumaczyć jako rzecz wyproszoną. Jeśli bowiem przyjąć, że tematem jest „prec”, to w takim razie słowo to może pochodzić od rzeczownika „prex” (prec-s), co oznacza żarliwą prośbę, błaganie, modlitwę. Wydaje się, że tego rodzaju znaczenie stanowi bodaj najbardziej podstawową intuicję, wedle której należy postrzegać wyrażenie „prekariat”. Aczkolwiek nietrudno zauważyć, że słowo to bliskie jest także złożeniu łacińskich wyrazów: pre i caritas (dobroczynność, czynna miłość bliźniego). Złożenie to zdaje się opisywać kondycję czegoś (lub kogoś), o co „trzeba się zatroszczyć” (w angielskim precarity kryje się czasownik to care, czyli dbać, troszczyć się, przejmować się czymś, opiekować się)2.

Skojarzenie prekariatu z proletariatem zdaje się akcentować klasowy sens tego pojęcia. Od razu jednak należy zaznaczyć, że nie chodzi tu o klasę społeczną w rozumieniu marksistowskim (stosunek do środków produkcji) czy Weberowskim (predykator szans życiowych). Jeśli prekariat rzeczywiście można postrzegać jako nową i rosnącą liczebnie grupę (klasę) socjoekonomiczną, to z konieczności musi on stać się przedmiotem szczególnego zainteresowania polityki społecznej i gospodarczej ${ }^{3}$.

Za twórcę pojęcia „prekariat” zwykle uznaje się Guya Standinga — brytyjskiego ekonomistę, profesora Uniwersytetu w Bath, specjalistę w zakresie bezpieczeństwa socjalnego i eksperta Międzynarodowej Organizacji Pracy. Jednakże to powszechne przekonanie rozmija się z prawdą. Jak się okazuje, pojęcie to stosowali socjologowie francuscy już w latach 80. na określenie sytuacji pracowników zatrudnionych tymczasowo. Pojęciem tym posługiwali się m.in.: Paul-Michel Foucault (francuski filozof i socjolog), Antonio Negri (włoski etyk i filozof), Pierre-Félix Bourdieu (francuski socjolog i antropolog) czy Jürgen Habermas (niemiecki filozof i socjolog) ${ }^{4}$.

Bez wątpienia jednak to Standing upowszechnił pojęcie prekariatu, broniąc hipotezy, że trzeba tę nową kategorię kojarzyć $\mathrm{z}$ wyłaniającą się odrębną, wysoce zróżnicowaną grupą socjoekonomiczną o globalnym zasięgu. Prekariat definiuje on jako rodzaj nowej

1 Por. A. Kolek, „Prekariat” jako nowa klasa społeczna. Geneza, istota, wyzwania, https://www.researchgate.net/publication/260082284 (dostęp: 25 października 2016); J. Mazur, Prekariat jako wyzwanie dla katolickiej nauki społecznej, „Dissertationes Paulinorum” 25, 2016, s. 45-50.

2 Por. J. Mazur, op. cit., s. 46-47; K. Cymbranowicz, Prekariat - nowe zjawisko na rynku pracy w Polsce, „Annales. Etyka w życiu gospodarczym” 19, 2015, nr 2, s. 18-19.

3 O celach i zadaniach polityki społecznej zob. w: Polityka społeczna. Teorie, pojęcia, problemy, red. M. Lavalette, A. Pratt, przeł. P. Jaworski, Warszawa 2010.

${ }^{4}$ K. Cymbranowicz, op. cit., s. 18, przypis 1. 
klasy społecznej per analogiam do dawnego proletariatu. We współczesnej strukturze społecznej wyróżnia Standing siedem odrębnych klas. Są to: elity (ang. global citizens), salariat, techniczni profesjonaliści (ang. proficians), klasa pracująca/pracownicy fizyczni, prekariat (ang. precariat), bezrobotni (ang. unemployed), niezatrudniani/nieprzystosowani społecznie (ang. group of socially ill misfits) ${ }^{5}$.

Wedle Standinga najbardziej charakterystyczną cechą prekariatu jest niepewność. Stan niepewności to nie tylko „uboga w treści, niepewna i nisko płatna praca”, ale także brak poczucia zawodowej tożsamości i możliwości rozwoju kariery zawodowej. Zdaniem Standinga prekariusz to swego rodzaju proletariusz XXI w., który funkcjonuje w warunkach ciągłej niepewności, mającej charakter wielowymiarowy. Owa niepewność wyraża się w typowych dla prekariatu postawach „4a” (ang. anger - pol. gniew, złość; anomie - dezorganizacja, frustracja; anxiety - niepokój; alienation - alienacja, wyobcowanie), które w oczywisty sposób prowadzą do negatywnych skutków odczuwalnych w wymiarze społecznym i ekonomicznym ${ }^{6}$.

Intuicja Standinga wydaje się być cenna, gdyż pozwala z niemałą wnikliwością spojrzeć w przyszłość obecnego porządku społecznego i ekonomicznego. Otóż prekariat, jakby unieważniając swoim zaistnieniem tradycyjny porządek klasowy, może w niedługim czasie stać się podmiotem uniwersalnym; podmiotem globalnej zmiany, której przeprowadzenie nie będzie już leżało w interesie tylko państw pogrążonych w niedorozwoju, ale wszystkich ofiar neoliberalnego kapitalizmu.

Ryszard Szarfenberg z Uniwersytetu Warszawskiego, starannie rozróżniając trzy pojęcia: prekarność, prekaryjność i prekariat, nie bez racji utrzymuje, że terminy te pochodzą z języka angielskiego i francuskiego: ang. precariousness, precarity; fr. précarité. Precarity oznacza sytuację niepewną, niestabilną, gdy osobom, grupom lub całym społecznościom brakuje zabezpieczenia przed jej negatywnymi skutkami. Natomiast „proletariat” oznacza - jak wiadomo - robotników, pracowników najemnych ujętych łącznie jako jedna klasa społeczno-ekonomiczna o dużym znaczeniu politycznym ${ }^{7}$.

Prekariat jest bez wątpienia nową kategorią społeczną, która coraz bardziej ujawnia swoją obecność w ponowoczesnym świecie. W opracowaniach słownikowych na ogół przyjmuje się, że jest to kategoria charakterystyczna dla okresu późnego kapitalizmu. Ponadto zdaniem wielu badaczy prekariat w znacznym stopniu kształtuje oblicze ponowoczesnego społeczeństwa, zwłaszcza rynek pracy i jego instytucje.

Pomimo zróżnicowania opinii na temat prekariatu jako kategorii społecznej, istnieje niemal powszechna zgoda co do postrzegania samego zjawiska. Łączy ono w sobie następujące cechy: przeważnie młody wiek, zatrudnienie tymczasowe lub jego czasowy brak, niskie dochody, brak mieszkania, a także często brak rodziny lub niechęć do jej zakłada-

${ }^{5}$ G. Standing, Prekariat. Nowa niebezpieczna klasa, przeł. K. Czarnecki, P. Kaczmarski, M. Karolak, Warszawa 2014, s. 102-116.

6 Ibidem, s. 60.

7 Por. R. Szarfenberg, Prekarność, prekaryjność, prekariat - krótkie wprowadzenie (tekst powstał w ramach projektu Zakładu Teorii i Metodologii Polityki Społecznej oraz Zakładu Polityki Społecznej w Środowisku Lokalnym — działających w Instytucie Polityki Społecznej Uniwersytetu Warszawskiego), http:// rszarf.ips.uw.edu.pl/pdf/prekariat3.5.pdf (dostęp: 22 marca 2017). 
nia z uwagi na brak stabilności życiowej (egzystencja pozbawiona perspektyw życiowych, zwłaszcza planów finansowych na przyszłość $)^{8}$. Dlatego istnieje potrzeba pogłębionej refleksji, która zdolna byłaby rozpoznać szanse i zagrożenia związane z pojawieniem się prekariatu. Z oczywistych względów jest to zadanie szczególnie ważne dla polityki społecznej.

Problematyka prekariatu stała się ostatnio przedmiotem pogłębionego namysłu o charakterze interdyscyplinarnym. Dla przykładu warto w tym miejscu odnotować przynajmniej kilka tego rodzaju wydarzeń, które wskazują na zainteresowanie zjawiskiem prekariatu wielu ośrodków zróżnicowanych ideowo i politycznie. Zagadnienie prekariatu zostało poruszone podczas utajnionej narady Klubu Bilderberg, który konferował w dniach 19-22 maja 2016 r. w niemieckim Dreźnie. Politycy, prezesi dużych banków i potężnych korporacji na spotkaniu w hotelu Taschenbergpalais Kempinski poruszyli m.in. temat: Prekariat i zanik klasy średniej.

W roku poprzednim, a więc 2015, 18 kwietnia, na Uniwersytecie Łódzkim odbyła się - zorganizowana przez Wydział Zarządzania - debata na temat: Prekariat - nowa niebezpieczna klasa ekonomiczna, a 8 czerwca tegoż roku prof. Elżbieta Kryńska z Uniwersytetu Łódzkiego, podczas XII Ogólnopolskiego Zjazdu Katedr Ekonomii w Międzyzdrojach, wygłosiła referat pt. Segmentacja współczesnego rynku pracy - prekariat i co dalej?

Z kolei podczas dorocznej ogólnopolskiej konferencji wykładowców katolickiej nauki społecznej, zorganizowanej w dniach 20-22 czerwca 2016 r. w Częstochowie na Jasnej Górze, został podjęty temat przewodni: Prekariat. Perspektywa katolickiej nauki społecznej. Przedmiotem refleksji był prekaryzm, względnie prekariat, w kontekście wyzwań, jakie stawia ponowoczesność. Ciekawe były wystąpienia prof. Krzysztofa Wieleckiego z Uniwersytetu Kardynała Stefana Wyszyńskiego (mówił o prekariacie w aspekcie socjologicznym), prof. Józefiny Hrynkiewicz z Uniwersytetu Warszawskiego (analiza zjawiska z punktu widzenia polityki społecznej) czy prof. Ireny Lipowicz, byłej Rzecznik Praw Obywatelskich (Prekariat a prawa człowieka). Tekst swojego wystąpienia przesłała również minister Elżbieta Rafalska (Ministerstwo Rodziny, Pracy i Polityki Społecznej). Wskazała w nim na powodowane przez zjawisko prekariatu najważniejsze wyzwania i zadania stojące przed kierowanym przez nią resortem.

\section{Prekaryjna praca w optyce polskiej polityki społecznej}

Należy zaznaczyć, że w Polsce dyskusja na temat zjawiska, jakim jest prekariat, została zainicjowana na forum polityki społecznej z chwilą ukazania się raportu Młodzi 2011. Jego głównym autorem jest prof. Krystyna Szafraniec z Uniwersytetu Mikołaja Kopernika w Toruniu. Przywołany dokument prezentuje wielowymiarową diagnozę interdyscyplinarnego zespołu, który w latach 2010-2011 spotykał się w Kancelarii Prezesa Rady Ministrów pod kierunkiem ministra Michała Boniego, szczególnie analizując sytuację ludzi młodych na polskim rynku pracy ${ }^{9}$.

\footnotetext{
8 Por. K. Cymbranowicz, op. cit., s. 22.

9 Por. ibidem, s. 21-22.
} 
Jednakże w tej części rozważań wykorzystany zostanie nowszy materiał. Będzie nim tekst wystąpienia Elżbiety Rafalskiej, przedłożony podczas wspomnianej konferencji jasnogórskiej w 2016 r. Prezentacja, o której mowa, została zatytułowana: Prekariat w perspektywie wyzwań i zadań stojących przed Ministerstwem Rodziny, Pracy i Polityki Społecznej.

\section{Rozpoznanie zjawiska pracy prekaryjnej}

Wedle minister Elżbiety Rafalskiej zjawisko pracy prekaryjnej ściśle związane jest z utrzymującym się, względnie trwałym, podziałem na rynku pracy - zwanym segmentacją lub dualizmem. Podział ten polega na tym, że istnieją dwie grupy pracowników. Pierwsza z nich to pracownicy etatowi, którzy cieszą się większą stabilnością zatrudnienia obwarowaną okresem wypowiedzenia, a także przewidywalną ścieżką kariery. Druga grupa to pracownicy pozostali, wykonujący swoją pracę w nietypowych formach zatrudnienia na umowach cywilnoprawnych, jako samozatrudnieni lub w szarej strefie. Pracujący na umowach nietypowych, w odróżnieniu od osób świadczących pracę w oparciu o umowy kodeksowe, nie mają bowiem dostępu do szerokiego katalogu praw zagwarantowanych Kodeksem pracy (podstawowe zasady bezpieczeństwa, odpłatny urlop wypoczynkowy czy regulacje dotyczące czasu pracy) ${ }^{10}$.

Na podstawie danych gromadzonych przez Ministerstwo Rodziny, Pracy i Polityki Społecznej można przyjąć, że Polska jest krajem o wyjątkowo wysokim udziale pracujących w oparciu o umowy czasowe w ogóle zatrudnionych. W roku 2015 udział umów czasowych wyniósł 28\% i był najwyższy wśród krajów Unii Europejskiej (średnia dla całej UE w roku 2015 wyniosła $14,2 \%)^{11}$.

Popularność umów czasowych wśród polskich pracodawców wzrosła w związku z globalnym kryzysem na rynkach finansowych w latach 2007-2011. Polscy przedsiębiorcy w czasie spowolnienia gospodarczego i związanej z tym niepewności wykorzystywali szereg instrumentów, których celem było tzw. przechowanie zatrudnienia, by w fazie oczekiwanego ożywienia mieli możliwość szybszego, mniej kosztownego zwiększenia produkcji bez ponoszenia kosztów nowej rekrutacji zespołu. W ten sposób mogą elastycznie regulować zatrudnienie w zależności od aktualnej koniunktury ${ }^{12}$.

10 Informacja na podstawie autoryzowanego tekstu minister E. Rafalskiej pt. Prekariat w perspektywie wyzwań i zadań stojących przed Ministerstwem Rodziny, Pracy i Polityki Społecznej, zaprezentowanego podczas konferencji Prekariat. Perspektywa katolickiej nauki społecznej (Częstochowa-Jasna Góra, 21 czerwca 2016 r.).

11 Odnośnie do statystyki związanej z zatrudnieniem Ministerstwo Rodziny, Pracy i Polityki Społecznej bazuje na danych dostarczanych głównie przez GUS, a także częściowo przez Eurostat, oraz wykorzystuje informacje Ministerstwa Finansów dotyczące rozliczenia podatku dochodowego od osób fizycznych (szacunki skali zatrudnienia na podstawie umów cywilnoprawnych). Informacja na podstawie autoryzowanego tekstu minister E. Rafalskiej (op. cit.).

12 Indeks prawnej ochrony zatrudnienia (Employment Protection Legislation, EPL) publikowany przez OECD dowodzi, że Polska charakteryzuje się stosunkowo wysokim stopniem ochrony przed zwolnieniami pracowników zatrudnionych na podstawie umów na czas nieokreślony, przy jednocześnie relatywnie ela- 
Problem polega na tym, że pomimo obserwowanej poprawy sytuacji gospodarczej pracodawcy niechętnie rezygnują z osiągniętej struktury umów, przez co umowy cywilnoprawne stały się w Polsce podstawową ścieżką wejścia na rynek pracy — zarówno dla osób młodych, jak i tych, które próbują odzyskać zatrudnienie po okresie bezrobocia lub nieaktywności. Badania CBOS z 2015 r. wskazują, że pracownicy zatrudnieni na umowach cywilnoprawnych są wprawdzie zmuszeni do wyboru tej formy zatrudnienia, jednakże blisko 60\% deklaruje, że nie chciałoby zmienić formy zatrudnienia, jeśli oznaczałoby to spadek ich dochodów rozporządzalnych, a ponad połowa (53\%) deklaruje zadowolenie $\mathrm{z}$ tej formy zatrudnienia. Zapewne wynika to $\mathrm{z}$ faktu, że pracownicy wolą otrzymywać więcej „na rękę”, choć jednocześnie nie chcą funkcjonować poza ochroną praw pracowniczych i zabezpieczenia społecznego wynikających z umowy o pracę ${ }^{13}$.

Ze względu na niejednoznaczne oceny nietypowych form zatrudnienia przez samych pracowników kluczowym wyzwaniem - w ocenie Ministerstwa Rodziny, Pracy i Polityki Społecznej - jest ograniczenie nadużyć w stosowaniu tych umów. Według Państwowej Inspekcji Pracy główną przyczyną łamania prawa w tym zakresie było dążenie do maksymalnego ograniczania pozapłacowych kosztów pracy. W tym miejscu można tylko wyrazić zdziwienie, gdyż z etycznego punktu widzenia tendencja ta musi budzić zastrzeżenia. Najnowsze dane Eurostatu po raz kolejny dowodzą, że koszty pracy w Polsce są wyjątkowo niskie na tle innych państw UE. Przeciętny koszt jednej godziny pracy jest trzykrotnie niższy od średniej unijnej i wynosi około 8,6 euro (w całej UE kształtuje się on na poziomie 25,4 euro). W tej sytuacji udział pozapłacowych kosztów jest również niski ${ }^{14}$.

Jeśli za kryterium pracy prekaryjnej przyjąć fakt zatrudnienia na czas określony, to dane statystyczne wskazują, że liczba zatrudnionych w ramach nietypowych form zatrudnienia jest zjawiskiem coraz bardziej powszechnym. Udział pracujących na czas określony jest szczególnie wysoki wśród zatrudnionych w relatywnie niewielkich zakładach pracy oraz przy pracach sezonowych. Niezależnie od aktualnego statusu edukacyjnego, sektora gospodarki czy wcześniejszych doświadczeń zawodowych, główną cechą charakterystyczną prekaryjnej pracy jest wiek tych, którzy ją podejmują. Najwyższy udział pracujących na umowach czasowych jest w skrajnych grupach wieku — wśród absolwentów wchodzących na rynek pracy oraz studentów i uczniów łączących aktywność zawodową z kontynuowaniem edukacji, a także osób starszych, które łączą pracę na umowach-zleceniach z pobieraniem świadczenia (przed)emerytalnego czy rentowego ${ }^{15}$.

stycznych regulacjach w przypadku umów czasowych — stopień ochrony przed zwolnieniem pracowników na umowach na czas określony jest niemal dwukrotnie niższy od średniej dla krajów OECD (wartości indeksu EPL 2013), cyt. za: autoryzowany tekst minister E. Rafalskiej, op. cit.

13 Sytuacja zawodowa Polaków, CBOS, Komunikat z badań nr 147/2015, Warszawa, listopad 2015.

14 Płace $i$ koszty pracy, Eurostat - Statistics Explained, http://ec.europa.eu/eurostat/statistics-explained/index.php/Wages_and_labour_costs/pl (dostęp: 15 kwietnia 2017).

15 Wedle szacunków z 2011 r. wśród osób pracujących do 24 . roku życia 16\% stanowią osoby zatrudnione w oparciu o umowy cywilnoprawne. Wśród osób w wieku 25-34 zatrudnieni w oparciu o umowy cywilnoprawne stanowią 6\%. Drugą grupą wiekową pracującą w oparciu o umowy cywilnoprawne są osoby 
Poza niestabilnością zatrudnienia oraz ograniczonym dostępem do praw pracowniczych cechą charakterystyczną prekaryjnej pracy są relatywnie niskie zarobki. Według opracowania Kancelarii Prezesa Rady Ministrów z 2015 r. średnie miesięczne dochody osób pracujących na umowach cywilnoprawnych w roku 2015 wynosiły około 1,6 tys. zł netto, podczas gdy przeciętne zarobki osób zatrudnionych na umowach o pracę na czas nieokreślony sięgały 2,6 tys. zł netto, a pracujących na umowach kodeksowych na czas określony 2,2 tys. zł. Najwyższe były zarobki przedsiębiorców - około 3,9 tys. zł netto, a najniższe osób, które pracowały na czarno - około 1,5 tys. zł netto ${ }^{16}$.

W sumie trzeba przyznać, że Ministerstwo Rodziny, Pracy i Polityki Społecznej problem pracy prekaryjnej postrzega głównie w kontekście niestabilnego, nietrwałego zatrudnienia. Zjawisko prekariatu ujmuje $\mathrm{w}$ ramach analizy rynku pracy, odpowiednio interpretując dane statystyczne, zwłaszcza te, które dotyczą stopy bezrobocia i wskaźnika zatrudnienia. W tej optyce podejmuje działania na rzecz zmniejszenia skali zjawiska pracy prekaryjnej. Czyni to, zakładając niejako, że segmentacja rynku pracy jest niekorzystna zarówno dla obywateli, jak i dla gospodarki. Albowiem duży udział nietrwałego zatrudnienia oraz związana $\mathrm{z}$ tym częsta rotacja pracowników zniechęcają obie strony stosunku pracy do inwestycji w podnoszenie kwalifikacji, a to z kolei, wraz z niskimi wynagrodzeniami, hamuje innowacyjność polskich przedsiębiorstw.

\section{Działania Ministerstwa Rodziny, Pracy i Polityki Społecznej}

Ministerstwo Rodziny, Pracy i Polityki Społecznej wraz Ministerstwem Rozwoju podejmują działania, których celem jest zniechęcenie pracodawców do nadmiernego, czasem niezgodnego z prawem, wykorzystywania umów czasowych, poprzez zmniejszenie dysproporcji w kosztach zatrudnienia, jakie występują pomiędzy kodeksową umową o pracę a umową cywilnoprawną.

W tym kierunku idą chociażby następujące rozwiązania:

1. W celu ograniczenia skali nadużywania umów cywilnoprawnych na rynku pracy wprowadzono obowiązek odprowadzania składek do ZUS od wszystkich umów-zleceń, do kwoty co najmniej minimalnego wynagrodzenia za płacę. Przepisy te obowiązują od początku $2016 \mathrm{r}$.

2. Od 1 września 2016 r. weszła w życie ustawa o zmianie ustawy - Kodeks pracy, która zobowiązuje pracodawcę do potwierdzania na piśmie warunków zawartej z pracownikiem umowy o pracę przed dopuszczeniem pracownika do pracy (a nie - jak poprzednio - najpóźniej do końca pierwszego dnia pracy, co sprzyjało nadużyciom ze strony nieuczciwych pracodawców).

po 65. roku życia. Blisko $12 \%$ spośród nich zatrudnionych jest w oparciu o ten typ umowy. P. Poławski, Generacja prekariuszy na polskim rynku pracy, „Polityka Społeczna” 39, 2012, nr 9 (462), s. 16-23.

16 B. Więckowska, Źródła dochodów a składkowanie na ubezpieczenia społeczne, http://docplayer. pl/5922028-Zrodla-dochodow-a-skladowanie-na-ubezpieczenia-spoleczne.html (dostęp: 23 października 2017). 
3. W dniu 22 lipca 2016 r. została przyjęta ustawa o zmianie ustawy o minimalnym wynagrodzeniu za pracę (obowiązująca od 1 stycznia 2017 r.), która m.in. wprowadza minimalną stawkę godzinową za pracę dla umów-zleceń oraz umów o świadczenie usług w ramach samozatrudnienia. Minimalna stawka godzinowa obowiązuje w wysokości ponad 12 zł. Jej wysokość będzie corocznie waloryzowana o wskaźnik wzrostu minimalnego (miesięcznego) wynagrodzenia za pracę. Ustawa likwiduje także możliwość ustalania wynagrodzenia dla osób z krótkim stażem zawodowym (poniżej 1 roku) na poziomie $80 \%$ obowiązującego minimalnego wynagrodzenia. Ponadto, dodatek za pracę w porze nocnej nie jest wliczany do wynagrodzenia minimalnego ${ }^{17}$.

Rozwiązania podejmowane przez Ministerstwo Rodziny, Pracy i Polityki Społecznej w znacznej mierze wychodzą naprzeciw oczekiwaniom tych, których można by zaliczyć do prekariatu. Są one korzystne dla pracujących, ale z punktu widzenia pracodawców stanowią wzrost kosztów pracy. Dlatego istnieje zagrożenie, że część miejsc pracy, szczególnie tych o niskiej produktywności, niewymagających wysokich kwalifikacji, zostanie umiejscowiona w szarej strefie. Aby temu zapobiec, niezbędne są działania na rzecz rozwoju przedsiębiorczości. Pakiet takich działań został już opracowany w ramach prac międzyresortowego zespołu ds. małych i średnich przedsiębiorstw. Chodzi o to, by doprowadzić do zmniejszenia barier administracyjno-formalnych, które stanowią często znaczący koszt dla małych firm.

Ogromnie ważny wydaje się fakt, iż działania na rzecz rozwoju przedsiębiorczości, kryjące w sobie negację „filozofii” pracy prekaryjnej, zostały ostatecznie uwzględnione w przyjętej przez Radę Ministrów w dniu 14 lutego 2017 r. uchwale dotyczącej Strategii na rzecz Odpowiedzialnego Rozwoju do roku 2020 (z perspektywą do 2030 r.), czyli tzw. planie Morawieckiego ${ }^{18}$. Warto nadmienić, że przyjęta strategia jest dziełem przede wszystkim Ministerstwa Rozwoju, ale znaczny udział w jej przygotowaniu i realizacji ma Ministerstwo Rodziny, Pacy i Polityki Społecznej, a także inne resorty oraz partnerzy społeczni. Dokument jest nową wizją Polski. Wpisuje się w proces wspierania takiego rynku pracy, któremu obca jest praca prekaryjna.

Czy jednak konsekwentna realizacja planu Morawieckiego doprowadzi do przezwyciężenia problemu pracy prekaryjnej? Analizując przywołaną strategię, niepodobna nie przyznać, że przyjmuje ona właściwy kierunek, w jakim powinna pójść polska polityka społeczna, jak również powiązana z nią polityka gospodarcza. Nie można jednak zmagań z pracą prekaryjną sprowadzać wyłącznie do działań, które wymierzone są przeciw niestabilnemu zatrudnieniu, powodującemu zwykle ograniczenie dostępu do praw pracowniczych i charakteryzującemu się relatywnie niskimi zarobkami. Trzeba po prostu uzdrowić rynek pracy jako taki czy nawet samą pracę, oczywiście w znaczeniu podmiotowym. Albowiem dziś, zważywszy na występujący zamęt w szeroko rozumianej kulturze pracy, nie bardzo wiadomo, czym jest praca: prawem, obowiązkiem, towarem, luksusem, karą, przywilejem? Dokonujące się przemiany ekonomiczne i społeczne, połączone

17 Informacja na podstawie autoryzowanego tekstu minister E. Rafalskiej, op. cit.

18 Por. Ministerstwo Rozwoju, „Biuletyn Informacji Publicznej”, https://www.mr.gov.pl/strony/aktualnosci/strategia-na-rzecz-odpowiedzialnego-rozwoju-z-akceptacja-rzadu/ (dostęp: 14 kwietnia 2017). 
z kryzysem gospodarczym, sprawiają, że odpowiedź na to pytanie kryje w sobie niemałe trudności. Wydaje się, że przed takim dylematem stają szczególnie ci, którzy podejmują pracę prekaryjną.

\section{Dylematy pracy prekaryjnej}

Ludzie uwikłani w rzeczywistość prekariatu żyją w ciągłej niepewności jutra i prowadzą życie bez możliwości planowania. W polskich warunkach na ogół zatrudniani są na czas określony, dopóki jest to możliwe, po czym są zwalniani i zatrudniani na nowo. Mają ograniczony dostęp do kredytów, nie podlegają ochronie przez związki zawodowe ani przez prawo pracy w takim samym zakresie, jak pracownicy zatrudnieni na stabilnych umowach. Istnienie coraz większej grupy utożsamianej z prekariatem powoduje, iż osoby posiadające zatrudnienie pracują ponad miarę, często na granicy wyzysku ${ }^{19}$.

Prekaryjna praca prowadzi do społecznie niekorzystnych zjawisk. Można by je krótko scharakteryzować jako „marnowanie mózgów”, pozbawianie odpowiednich szans na rozwój ludzi młodych, którzy mają poczucie, że stanowią pokolenie zbędne. W ten sposób podważony zostaje etos pracy. Przestaje być ona służbą drugiemu człowiekowi, a staje się przede wszystkim sposobem zdobycia środków do życia, jak również narzędziem dominacji pracodawców nad pracownikami.

Wydaje się, że dla zrozumienia i rozwiązania problemów pracy prekaryjnej ważne jest uwzględnienie perspektywy makroekonomicznej. Okazuje się, że opieranie strategii rozwoju gospodarki polskiej na mitach, takich jak ten, że w nowoczesnych gospodarkach przemysł odgrywa drugorzędną rolę i jako taki w zasadzie nie powinien podlegać ochronie państwa, doprowadziło do likwidacji ogromnej liczby miejsc pracy. Przyczyniają się do tego także dumpingowe ceny wielu importowanych towarów, które w normalnych warunkach można by wyprodukować w Polsce. Ponadto w samych usługach nie można stworzyć wystarczającej liczby miejsc pracy, a zaawansowane technologie, powodujące rozwój społeczeństw zachodnich, stają się dla Polski i całej Europy Środkowo-Wschodniej coraz trudniej dostępne. Zdaniem wielu ekonomistów i socjologów państwa tej części Europy, łącznie z Polską, wchodzą — owszem, zdaje się, że już weszły — na ścieżkę rozwoju zależnego, w którym gospodarki tych krajów pełnią funkcję służebną (jako zasób taniej siły roboczej oraz rynek zbytu) wobec krajów rozwiniętego Zachodu ${ }^{20}$.

19 Por. J. Urbański, Prekariat i nowa walka klas. Przeobrażenia współczesnej klasy pracowniczej i jej form walki, Warszawa 2014.

20 Por. A. Hennel-Brzozowska, O pracy i o dramacie pracy młodych dialog wielodyscyplinarny. Przedmowa, [w:] Młody człowiek wobec pracy, wyzysku i bezrobocia. Perspektywy fides i ratio, red. eadem, Kraków 2014, s. 5-17. Cytowana publikacja jest pokłosiem międzynarodowej konferencji naukowej Młody człowiek wobec pracy, wyzysku i bezrobocia, która odbyła się w czerwcu 2013 r. w Polskiej Akademii Umiejętności w Krakowie. Organizatorzy konferencji to: Międzynarodowe Towarzystwo Naukowe „Fides et Ratio”, Wydział Filologiczny Polskiej Akademii Umiejętności, Katedra Psychologii Uniwersytetu Pedagogicznego w Krakowie oraz Polskie Towarzystwo Psychologiczne - Oddział Krakowski. 
Nie ulega wątpliwości, że problem pracy prekaryjnej staje przed polityką społeczną w Polsce jako niemałe wyzwanie. Do jego rozwiązania, przynajmniej częściowego, nie wystarczy zwalczanie niepewnego, niestabilnego zatrudnienia, lecz - warto powtórzyć to raz jeszcze - należy uzdrowić samą pracę, przywrócić jej podmiotową godność. Aby pójść w tym kierunku, należy rozpocząć od walki z bezrobociem. Chodzi jednak nie o statystyczne pozbycie się problemu poprzez masową emigrację zarobkową, ale o takie obniżanie stopy bezrobocia, któremu towarzyszy odpowiedni wzrost wskaźnika zatrudnienia.

Interesująca pod tym względem jest uwaga prof. Józefiny Hrynkiewicz z Uniwersytetu Warszawskiego, która sugeruje, że gdyby polskich emigrantów zarobkowych uznać za bezrobotnych (emigrują za pracą, gdyż nie znajdują jej w kraju), to stopę bezrobocia trzeba by powiększyć około 2,5-krotnie ${ }^{21}$. Przykładowo, w samym tylko $2015 \mathrm{r}$. za pracą lub/i w związku z pracą wyemigrowało z Polski $2 \mathrm{mln} 438$ tys. osób ${ }^{22}$. Według danych GUS z końca grudnia 2015 r. stopa bezrobocia w Polsce wprawdzie się zmniejszyła do $9,7 \%{ }^{23}$, ale gdy uwzględni się emigrantów zarobkowych i pomnoży ją przez 2,5 - osiąga poziom $24,3 \%$. Tak wysoki wskaźnik, jakkolwiek by był interpretowany, musi budzić uzasadniony niepokój, gdyż w oczywisty sposób generuje problem pracy prekaryjnej.

Być może przywoływany powyżej Standing ma rację, kiedy stawia hipotezę, że do głównych czynników generujących prekarność należą: neoliberalna globalizacja i uelastycznienie procesu produkcyjnego. Pod tym względem szczególnie ważny jest jeden z elementów globalizacji, mianowicie proces nieustannego wyrównywania cen czynników produkcji ${ }^{24}$.

Niektórzy badacze podają jednak w wątpliwość odwoływanie się do kategorii prekariatu, gdyż - ich zdaniem - jest ona bezużyteczna, skoro obejmuje niemal wszystkich pracujących $^{25}$. Oparta jest wszakże na kryterium niepewności samej pracy. Niemniej jednak wydaje się, że praca prekaryjna jest zjawiskiem społecznie nieobojętnym. Istnieje oczywisty związek pomiędzy elastycznymi formami zatrudnienia a negatywnymi uwarunkowaniami rynku pracy. Sposób postrzegania tego zjawiska nieuchronnie wiąże się z troską o człowieka pracy, jego sytuację egzystencjalną.

Warto w tym miejscu zauważyć, że prekariat jest kategorią, która usiłuje scalić wiele dotychczasowych kategorii, charakteryzujących ludzi uznawanych za będących w gorszej sytuacji na rynku pracy, np. ubogich pracowników, pracowników tymczasowych (brak stałych umów, brak ochrony przed zwolnieniem, brak urlopu), samozatrudnionych z przymusu czy stażystów. Dla uchwycenia istoty prekariatu nie bez znaczenia jest

21 Opinia prof. Józefy Hrynkiewicz zawarta w referacie: Fenomen prekariatu jako wyzwanie dla polityki społecznej wygłoszonym podczas konferencji Prekariat. Perspektywa katolickiej nauki społecznej.

22 Cyt. za: ibidem.

${ }^{23}$ Liczba bezrobotnych zarejestrowanych oraz stopa bezrobocia wedtug województw, podregionów i powiatów. Stan w końcu grudnia 2015 r., GUS, http://stat.gov.pl/obszary-tematyczne/rynek-pracy/bezrobocie-rejestrowane/liczba-bezrobotnych-zarejestrowanych-oraz-stopa-bezrobocia-wedlug-wojewodztwpodregionow-i-powiatow-stan-w-koncu-grudnia-2015-r-,2,40.html (dostęp: 30 marca 2017).

24 G. Standing, Karta prekariatu, przeł. P. Juskowiak, P. Kaczmarski, M. Szlinder, Warszawa 2015.

25 Por. J. Tyrowicz, Prekariat nie istnieje (wywiad przeprowadzony przez Ł. Pawłowskiego), „Kultura Liberalna" 30 czerwca 2015, nr 338 (26/2015). 
zrozumienie, na czym polega jego przeciwieństwo. W gruncie rzeczy chodzi o taką pracę, która jest bezpieczna, pewna i dobrej jakości.

W przemyśleniach Standinga godne uwagi są wskazane przez niego elementy stojące na straży pracy nieprekaryjnej. Należą do nich: polityka na rzecz pełnego zatrudnienia; ochrona przed arbitralnym zwolnieniem; istnienie realnych szans na zachowanie swojego miejsca w organizacji pracy czy możliwość rozwoju zawodowego związanego z tym miejscem; bezpieczeństwo i higiena wykonywanej pracy, regulacja czasu pracy; szanse na zdobycie i rozwijanie kwalifikacji zawodowych poprzez staże, praktyki itp.; odpowiednie regulacje płac, zwłaszcza minimalnej; ubezpieczenie społeczne; respekt dla prawa do zrzeszania się, strajku ${ }^{26}$.

Widać wyraźnie, że przywołane czynniki warunkujące związane z pracą bezpieczeństwo stanowią wyzwanie dla każdej autentycznej polityki społecznej, dla której roztropne staranie o dobro społeczne (socjalne) znajduje swoje ostateczne uzasadnienie w trosce o człowieka, jego godność i wynikające z tej godności prawa i obowiązki. Jeśli chodzi o prekariat czy pracę prekaryjną, postrzegane głównie w ramach kryterium niepewności i braku bezpieczeństwa, to nie tyle ma znaczenie terminologia, kwestia jej zasadności, ile powinien liczyć się fakt, że zagrożone zostało dobro człowieka w obszarze: rynku pracy, zatrudnienia, miejsca pracy, reprodukcji kwalifikacji, dochodu czy reprezentacji. Chodzi o to, aby zagrożenia te skutecznie przezwyciężyć. Nie będzie to możliwe, jeśli wpierw nie zostanie uszanowana godność pracy człowieka. Jest to zasadnicze kryterium pozwalające na ocenę samego zjawiska pracy prekaryjnej.

Zasada godności pracy ludzkiej prowokuje realizację takiej polityki społecznej, która uwzględniałaby przywołane powyżej czynniki stojące na straży pracy nieprekaryjnej. Pod tym względem jakże aktualne wydają się wskazania etyczne zawarte w encyklice $L a$ borem exercens Jana Pawła II ${ }^{27}$. W jej przesłaniu ważne jest zaakcentowanie takich kwestii, jak zasada prymatu pracy w znaczeniu podmiotowym (człowieka) nad jej znaczeniem przedmiotowym (techniką), godność pracy ludzkiej, solidarność ludzi pracy i ich uprawnienia, czy wreszcie elementy duchowości pracy. Encyklika uświadamia ekonomistom i politykom, zwłaszcza politykom społecznym, że „praca ludzka stanowi klucz, i to chyba najistotniejszy klucz, do całej kwestii społecznej, jeżeli staramy się ją widzieć naprawdę pod kątem dobra człowieka" 28 .

\section{Podsumowanie}

Chociaż zdaniem niektórych ekonomistów i socjologów kategoria prekariatu nie znajduje odpowiednika w realnym życiu społecznym czy gospodarczym, to jednak z całą pewnością istnieją poważne problemy związane z pracą, którą można identyfikować

${ }_{26}$ Por. G. Standing, Prekariat. Nowa niebezpieczna klasa..., s. 9 i passim.

27 Zob. Praca kluczem polityki społecznej. Materiały sympozjum w 25-lecie wydania encykliki „Laborem exercens" Jana Pawła II, red. J. Mazur OSPPE, Lublin 2007.

28 Jan Paweł II, Encyklika „Laborem exercens” (14 września 1981), [w:] Ewangelia pracy. Encyklika Jana Pawła II „Laborem exercens” wraz z komentarzem, red. ks. J. Chmiel, ks. S. Ryłko, Kraków 1983, s. 15. 
jako prekaryjną czy prekariacką. Problemów tych nie można nie dostrzegać, bo dotykają one konkretnych ludzi, których los powinien być otoczony troską ze strony polityki społecznej i polityki gospodarczej.

Zagadnienie pracy prekaryjnej jawi się jako niezwykle istotne z punktu widzenia niekorzystnych zjawisk zachodzących $w$ ponowoczesnych społeczeństwach, a więc także i w Polsce. Mimo że w dobie globalizacji główne procesy przemian zachodzą równolegle w wielu krajach, to jednak negatywne skutki tych procesów są dużo bardziej dotkliwe w tych państwach, które stosunkowo niedawno weszły na ścieżkę rozwoju gospodarki rynkowej. Do takich właśnie krajów należy Polska. Dlatego istnieje pilna potrzeba głębokiego namysłu nad pracą prekaryjną, co powinno skutkować przyjęciem odpowiednich działań w ramach polityki społecznej państwa. Ministerstwo Rodziny, Pracy i Polityki Społecznej wraz Ministerstwem Rozwoju podejmują inicjatywy, których celem jest zniechęcenie pracodawców do nadmiernego, czasem niezgodnego z obowiązującym prawem, wykorzystywania umów czasowych poprzez zmniejszenie dysproporcji w kosztach zatrudnienia między kodeksową umową o pracę a umową cywilnoprawną. Są to rozwiązania zmierzające we właściwym kierunku, ale z pewnością niewystarczające. Konieczne jest uwzględnienie perspektywy makroekonomicznej. Ponadto polityka walki z bezrobociem i dążenie do wzrostu wskaźnika zatrudnienia muszą iść $\mathrm{w}$ parze z respektem dla podmiotowości ludzkiej pracy, jej godności postrzeganej w perspektywie etyki przyjaznej człowiekowi.

Być może problem pracy prekaryjnej, dziś będący przedmiotem rozeznania, któremu towarzyszą spory akademickie, niebawem stanie się rodzajem „kwestii prekariackiej”. Dla jej rozwiązania „pod kątem dobra człowieka”, podobnie jak i każdej innej kwestii społecznej, warto może posłużyć się kluczem, jakim jest praca ludzka postrzegana w duchu Laborem exercens.

\section{Bibliografia}

Cymbranowicz K., Prekariat - nowe zjawisko na rynku pracy w Polsce, „Annales. Etyka w życiu gospodarczym" 19, 2015, nr 2.

Hennel-Brzozowska A., O pracy i o dramacie pracy młodych dialog wielodyscyplinarny. Przedmowa, [w:] Młody człowiek wobec pracy, wyzysku i bezrobocia. Perspektywy fides i ratio, red. eadem, Wydawnictwo „Scriptum”, Kraków 2014.

Hrynkiewicz J., Fenomen prekariatu jako wyzwanie dla polityki społecznej, autoryzowany referat wygłoszony podczas konferencji Prekariat. Perspektywa katolickiej nauki społecznej (Częstochowa-Jasna Góra, 21 czerwca 2016 r.) - tekst w posiadaniu autora [JM].

Jan Paweł II, Encyklika „Laborem exercens” (14 września 1981), [w:] Ewangelia pracy. Encyklika Jana Pawła II „Laborem exercens” wraz z komentarzem, red. ks. J. Chmiel, ks. S. Ryłko, Polskie Towarzystwo Teologiczne, Kraków 1983.

Kolek A., „Prekariat” jako nowa klasa społeczna. Geneza, istota, wyzwania, https://www.researchgate.net/ publication/260082284 (dostęp: 25 października 2016).

Liczba bezrobotnych zarejestrowanych oraz stopa bezrobocia według województw, podregionów i powiatów. Stan w końcu grudnia 2015 r., http://stat.gov.pl/obszary-tematyczne/rynek-pracy/bezrobocie-rejestrowane/ liczba-bezrobotnych-zarejestrowanych-oraz-stopa-bezrobocia-wedlug-wojewodztw-podregionow-ipowiatow-stan-w-koncu-grudnia-2015-r-,2,40.html (dostęp: 30 marca 2017). 
Mazur J., Prekariat jako wyzwanie dla katolickiej nauki społecznej, „Dissertationes Paulinorum” 25, 2016.

Ministerstwo Rozwoju, „Biuletyn Informacji Publicznej”, https://www.mr.gov.pl/strony/aktualnosci/strategia-na-rzecz-odpowiedzialnego-rozwoju-z-akceptacja-rzadu/ (dostęp: 14 kwietnia 2017).

Płace $i$ koszty pracy, Eurostat - Statistics Explained, http://ec.europa.eu/eurostat/statistics-explained/index. php/Wages_and_labour_costs/pl (dostęp: 14 kwietnia 2017).

Polityka społeczna. Teorie, pojęcia, problemy, red. M. Lavalette, A. Pratt, przeł. P. Jaworski, Difin SA, Warszawa 2010.

Poławski P., Generacja prekariuszy na polskim rynku pracy, „Polityka Społeczna” 39, 2012, nr 9 (462).

Praca kluczem polityki społecznej. Materiały sympozjum w 25-lecie wydania encykliki "Laborem exercens" Jana Pawła II, red. J. Mazur OSPPE, Towarzystwo Naukowe KUL, Lublin 2007.

Rafalska E., Prekariat w perspektywie wyzwań i zadań stojących przed Ministerstwem Rodziny, Pracy i Polityki Społecznej, autoryzowana prezentacja podczas konferencji Prekariat. Perspektywa katolickiej nauki społecznej (Częstochowa-Jasna Góra, 21 czerwca 2016 r.) - tekst w posiadaniu autora [JM].

Standing G., Karta prekariatu, przeł. P. Juskowiak, P. Kaczmarski, M. Szlinder, Wydawnictwo Naukowe PWN, Warszawa 2015.

Standing G., Prekariat. Nowa niebezpieczna klasa, przeł. K. Czarnecki, P. Kaczmarski, M. Karolak, Wydawnictwo Naukowe PWN, Warszawa 2014.

Sytuacja zawodowa Polaków, GUS, Komunikat z badań nr 147/2015, Warszawa, listopad 2015.

Szarfenberg R., Prekarność, prekaryjność, prekariat - krótkie wprowadzenie (tekst powstał w ramach projektu Zakładu Teorii i Metodologii Polityki Społecznej oraz Zakładu Polityki Społecznej w Środowisku Lokalnym — działających w Instytucie Polityki Społecznej Uniwersytetu Warszawskiego), http://rszarf. ips.uw.edu.pl/pdf/prekariat3.5.pdf (dostęp: 22 marca 2017).

Tyrowicz J., Prekariat nie istnieje (wywiad przeprowadzony przez Ł. Pawłowskiego), „Kultura Liberalna” 30 czerwca 2015, nr 338 (26/2015).

Urbański J., Prekariat i nowa walka klas. Przeobrażenia współczesnej klasy pracowniczej i jej form walki, Instytut Wydawniczy Książka i Prasa, Warszawa 2014.

Więckowska B., Źródła dochodów a składkowanie na ubezpieczenia społeczne, http://docplayer.pl/5922028Zrodla-dochodow-a-skladowanie-na-ubezpieczenia-spoleczne.html (dostęp: 23 października 2017).

\section{The problem of precarious work in the context of the discussion on social policy in Poland}

Keywords: precariat, precarious work, employment contract, uncertain forms of employment, permanent employees, civil law agreement, unemployment, labour market

\section{Summary}

The text consists of two parts. The first is an introduction to the problem of precarious work. The expression "precarious work" itself is derived from the word "precariat". This term refers to people who are forced to undertake poor quality employment which is mostly precarious, temporary, low-paid, lacks promotion prospects, and is undertaken on the basis of flexible contracts etc. The easiest way that the prekariat can be characterized is by using such references as "junk" contracts, unsecured employment, inhumane overtime, lack of professional identity, low pension contributions or their total absence

The second part of the text presents precarious work from the perspective of Polish social policy. Above all, a speech by Elżbieta Rafalska, the Minister for Family, Labour and Social Policy was used. The speech was presented during a national conference entitled "Prekariat. The Perspective of Catholic Social Science", held in Częstochowa, Jasna Góra on 21 June 2016. 
Precarious work leads to negative social phenomena. They can be characterized briefly as "brain wasting", which deprives young people of the opportunity to develop, and gives them a sense of being an unnecessary generation. In this way, the ethos of work is undermined. It ceases to be a service to another person, and becomes primarily a means of obtaining means of living and an instrument of the employer's domination over employees.

Thee dilemmas posed by precarious work create considerable challenges for social policy in Poland. It is not enough to combat precarious, unstable employment, but work itself needs to be healed, so that its dignity is restored. That is why one should start with the fight against unemployment. Guy Standing's ideas are worthy of consideration, as they propose a social policy that supports non-precarious work. In this respect, the ethical guidelines contained in the John Paul II's encyclical "Laborem exercens" still appear to be valid. 